\title{
Gel Electrophoresis
}

National Cancer Institute

\section{Source}

National Cancer Institute. Gel Electrophoresis. NCI Thesaurus. Code C18091.

Gel electrophoresis is a method of separating large molecules (such as DNA fragments or proteins) from a mixture of similar molecules by electrophoretic filtration through a gelatinous matrix. Subject to an electric field, each molecule in the sample mixture migrates through the matrix at a different rate, depending mainly on electrical charge and size, resulting in spatial separation within the matrix of each molecular species in the sample mixture. Agarose and acrylamide in a cylindrical tube or slab gel are commonly used media for electrophoresis of proteins and nucleic acids. 